Images in...

\title{
Genital ulcers: do not forget Behçet disease
}

\author{
Susana Maia, ${ }^{1}$ Alexandra Martins, ${ }^{2}$ Celeste Santos, ${ }^{1}$ François Alves ${ }^{2}$ \\ ${ }^{1}$ Department of Gynaecology Obstetrics, Faro's Hospital, Faro, Portugal; \\ ${ }^{2}$ Department of Internal Medicine, Faro's Hospital, Faro, Portugal
}

Correspondence to Dr François Alves, jeanfrancoisalves@sapo.pt

\section{DESCRIPTION}

A 22-year-old, previously healthy, woman was referred to our department for genital ulcers present for more than 1 year, with no resolution to the various treatments prescribed. At physical examination, the patient presented a painful ulcer with a central necrotic base and clean margin about $10 \mathrm{~mm}$ in diameter on the right labia majora (figure 1) and a similar lesion at the cervix (figure 2). Multiple painful aphthous like ulcers morphologically similar to genital ulcers of the oral cavity (figures 3 and 4) and folliculitis-like lesions on the legs (figure 5) were found. The diagnostic exams revealed only an elevated

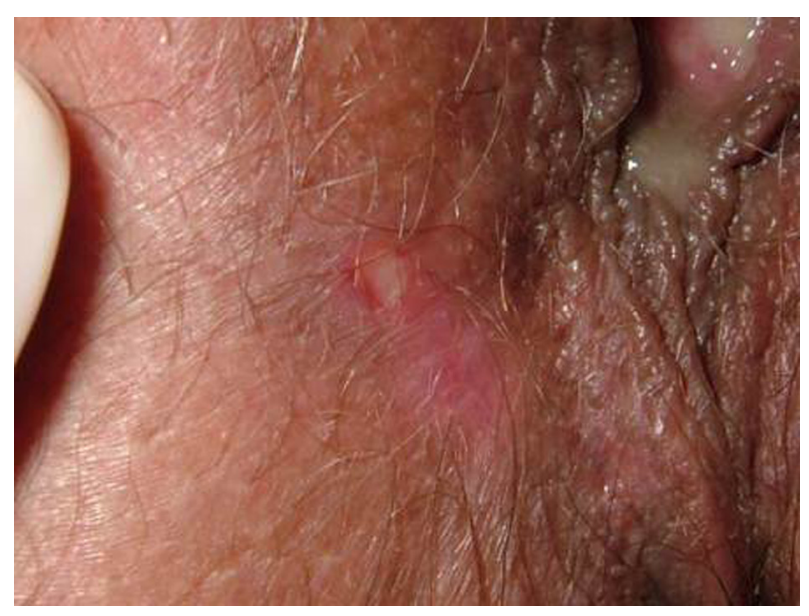

Figure 1 Genital ulcer on the right labia majora.

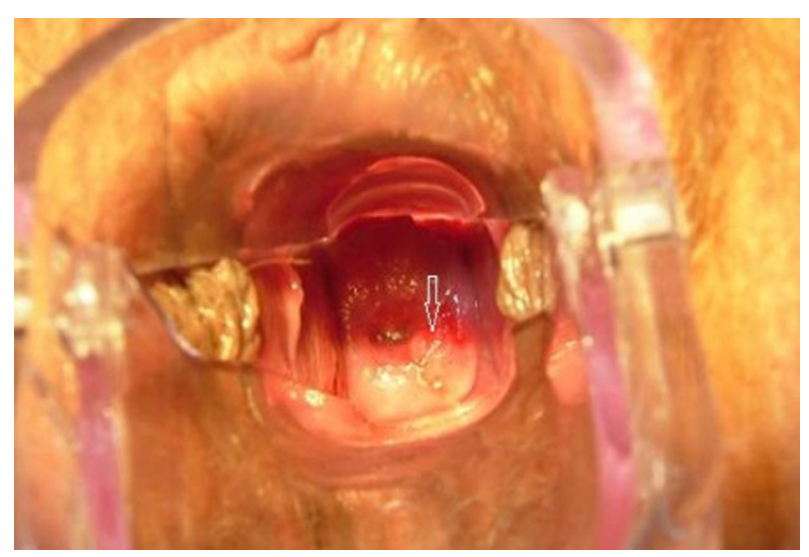

Figure 2 Genital ulcer at the cervix. erythrocyte sedimentation rate. As this patient met the criteria of the International Study Group for Beçhet disease, ${ }^{1}$ based on the occurrence of symptoms and signs that are compatible with the disease, the diagnostic was made. The criteria include recurrent oral ulceration with two of the following four criteria: recurrent genital ulcerations, eye lesions (uveitis or retinal vasculitis), skin lesions (erythema nodosum or foliculitis) and or positive 'pathergy test' (Occurrence of a small red bump or sterile pustule to any intracutaneous insult). The investigation shows no involvement of cardiovascular, renal, gastrointestinal,

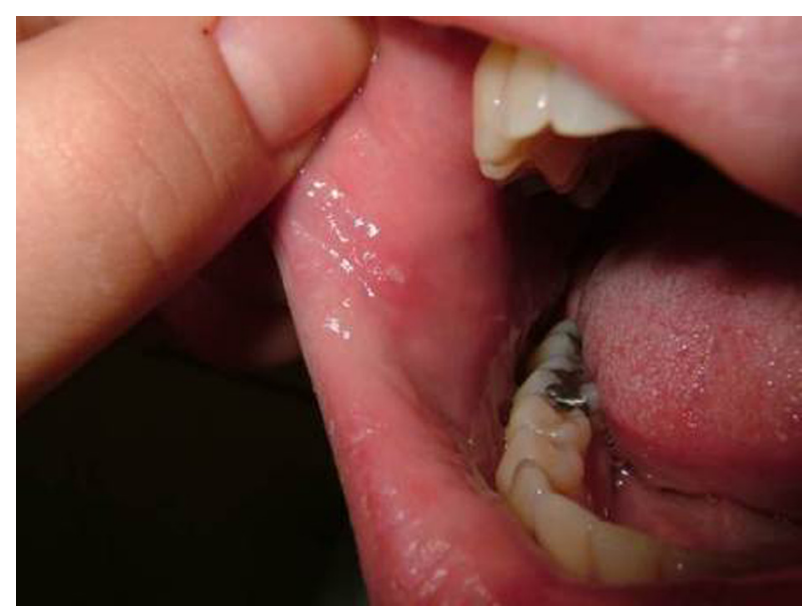

Figure 3 Aphthous like lesion of the oral cavity.

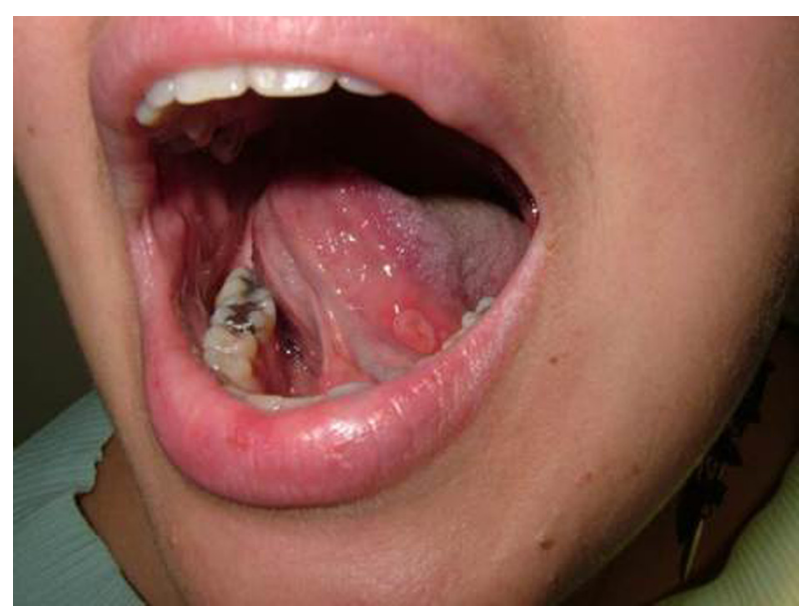

Figure 4 Aphthous like lesion of the tongue. 


\section{BMJ Case Reports}

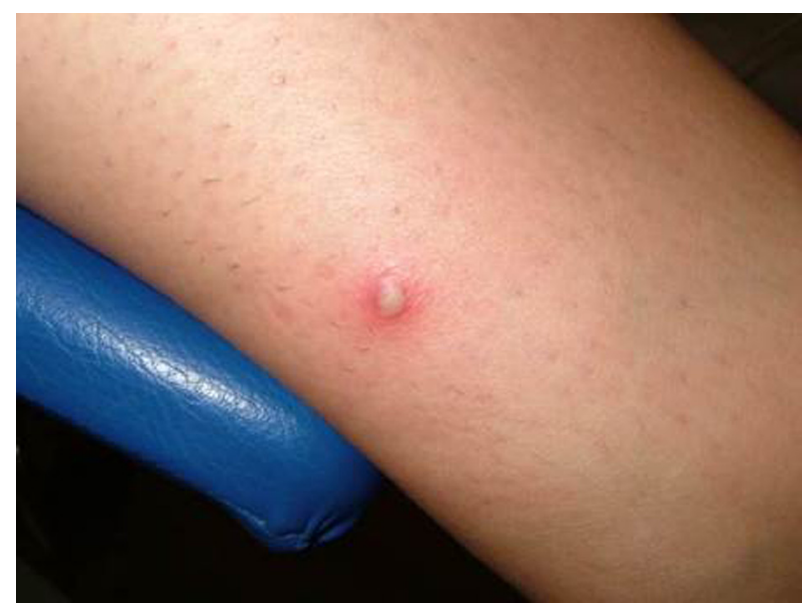

Figure 5 Folliculitis like lesions on the legs. pulmonary, urologic, joint or central nervous systems. Treatment was established by the Autoimmune Disease Unit and resolution of symptoms was achieved with the administration of corticotherapy and colchicin. Two years later, the patient had an uneventful pregnancy resulting in a normal infant.

\section{Competing interests None.}

\section{Patient consent Obtained.}

\section{REFERENCES}

1. International Study Group for Behçet's Disease. Criteria for diagnosis of Behçet's disease. Lancet 1990;335:1078-80.

2. Gomes CM, Giraldo PC, Gomes Fde A, et al. Genital ulcers in women: clinical, microbiologic and histopathologic characteristics. Braz J Infect Dis 2007:11:254-60.

3. Ideguchi H, Suda A, Takeno M, et al. Behçet disease: evolution of clinical manifestations. Medicine (Baltimore) 2011;90:125-32.

This pdf has been created automatically from the final edited text and images.

Copyright 2012 BMJ Publishing Group. All rights reserved. For permission to reuse any of this content visit http://group.bmj.com/group/rights-licensing/permissions.

BMJ Case Report Fellows may re-use this article for personal use and teaching without any further permission.

Please cite this article as follows (you will need to access the article online to obtain the date of publication).

Maia S, Martins A, Santos C, Alves F. Genital ulcers: do not forget Behçet disease. BMJ Case Reports 2012;10.1136/bcr.11.2011.5069, Published XXX

Become a Fellow of BMJ Case Reports today and you can:

- Submit as many cases as you like

- Enjoy fast sympathetic peer review and rapid publication of accepted articles

- Access all the published articles

- Re-use any of the published material for personal use and teaching without further permission

For information on Institutional Fellowships contact consortiasales@bmjgroup.com

Visit casereports.bmj.com for more articles like this and to become a Fellow

Keep up to date with all published cases by signing up for an alert (all we need is your email address) http://casereports.bmj.com/cgi/alerts/etoc 